\title{
Chromosomal targeting of replicating plasmids in the yeast Hansenula polymorpha
}

\author{
KlaAs Nico Faber, ${ }^{1}$ Gert Jan Swaving, ${ }^{1}$ Folkert Faber, ${ }^{2}$ Geert AB, ${ }^{2}$ Wim Harder, ${ }^{1}$ \\ Marten Veenhuis $^{1 *}$ and Peter Haima ${ }^{1} \dagger$ \\ ${ }^{1}$ Department of Microbiology, Biological Centre, University of Groningen, Kerklaan 30, 9751 NN Haren (Groningen), \\ The Netherlands \\ ${ }^{2}$ Department of Biochemistry, University of Groningen, Nijenborgh 4, 9747 AG Groningen, The Netherlands
}

(Received 31 March 1992; revised 7 July 1992; accepted 15 July 1992)

\begin{abstract}
Using an optimized transformation protocol we have studied the possible interactions between transforming plasmid DNA and the Hansenula polymorpha genome. Plasmids consisting only of a pBR322 replicon, an antibiotic resistance marker for Escherichia coli and the Saccharomyces cerevisiae LEU2 gene were shown to replicate autonomously in the yeast at an approximate copy number of 6 (copies per genome equivalent). This autonomous behaviour is probably due to an $H$. polymorpha replicon-like sequence present on the $S$. cerevisiae LEU2 gene fragment. Plasmids replicated as multimers consisting of monomers connected in a head-to-tail configuration. Two out of nine transformants analysed appeared to contain plasmid multimers in which one of the monomers contained a deletion. Plasmids containing internal or flanking regions of the genomic alcohol oxidase gene were shown to integrate by homologous single or double cross-over recombination. Both single- and multicopy (two or three) tandem integrations were observed. Targeted integration occurred in 1-22\% of the cases and was only observed with plasmids linearized within the genomic sequences, indicating that homologous linear ends are recombinogenic in $\boldsymbol{H}$. polymorpha. In the cases in which no targeted integration occurred, double-strand breaks were efficiently repaired in a homology-independent way. Repair of double-strand breaks was precise in 50-68\% of the cases. Linearization within homologous as well as nonhomologous plasmid regions stimulated transformation frequencies up to 15 -fold.
\end{abstract}

\section{Introduction}

The ability of the yeast Hansenula polymorpha to utilize methanol as a sole carbon and energy source renders this organism of considerable scientific and commercial interest. The biochemistry and physiology of methanol utilization has been studied extensively (for a recent review, see Van der Klei et al., 1991a). Part of the methanol metabolism is compartmentalized in peroxisomes which contain the enzyme alcohol oxidase (AO), catalysing the initial oxidation of methanol to formaldehyde. Under optimal expression conditions established in methanol-limited continuous culture, the AO protein constitutes up to $30-40 \%$ of cellular protein and is exclusively located in peroxisomes, which occupy over

* Author for correspondence. Tel. (050) 632176; fax (050) 635205.

† Present address: Nichols Institute Diagnostics, Nieuweweg 172, 6603 BT Wijchen, The Netherlands.

Abbreviations: AO, alcohol oxidase; DSB, double-strand break(s).
$80 \%$ of the total cell volume (Veenhuis et al., 1983). The ability of $\boldsymbol{H}$. polymorpha to express the AO gene at such high levels renders this organism a very attractive host for expressing heterologous genes under control of the strong AO promoter. Expression of heterologous genes this way has been reported for e.g. the plant gene $\alpha$-galactosidase (Fellinger et al., 1991; Sierkstra et al., 1991), the Escherichia coli $\beta$-lactamase (Eckart, 1988), L and S hepatitis B antigens (Shen et al., 1989; Janowicz et al., 1991) and human serum albumin (Hodgkins et al., 1990).

The induction, biogenesis and metabolic function of peroxisomes have been extensively studied in $H$. polymorpha. Proliferation and enzyme composition of the organelles can be precisely prescribed by manipulating growth conditions (for a review, see Veenhuis \& Harder, 1991). Recently, it was shown that peroxisomes are indispensable for growth of cells on methanol since they are essential in regulating the metabolic fluxes of formaldehyde, produced from methanol, over dissimi- 
latory and assimilatory pathways. Moreover, they confine the toxic byproduct of methanol oxidation, $\mathrm{H}_{2} \mathrm{O}_{2}$, close to its site of synthesis where it is decomposed efficiently by another peroxisomal enzyme, catalase (Van der Klei et al., 1991b). Consequently, mutants of $H$. polymorpha affected in peroxisome biogenesis/ assembly (Cregg et al., 1990) are unable to utilize methanol as sole carbon source.

Although much is known about the physiology, biochemistry and ultrastructure of $H$. polymorpha, and classical genetic methods are well developed (Gleeson \& Sudbery, 1988), our present knowledge of the molecular genetics is relatively poor. The main reason for this is that genetic transformation methods for this yeast have become available only recently. Furthermore, the transformation protocols published so far are either delicate or inefficient, or only successful when used with specific strains (Gleeson et al., 1986; Roggenkamp et al., 1986; Tikhomirova et al., 1988; Berardi \& Thomas, 1990). Studies at the molecular level have also been severely hampered by the absence of efficient procedures for plasmid integration, gene disruption and gene replacement. These methods of gene manipulation have been used in Saccharomyces cerevisiae and other fungi to generate null mutants, to modify genes or their mode of regulation, to clone and map genes and to stabilize homologous and heterologous genes (for a review, see Fincham, 1989). Although plasmid integrations by single or double cross-over recombination events have been reported recently (Sierkstra et al., 1991; Beburov et al., 1990; Hodgkins et al., 1990; Sudbery et al., 1988; Fellinger et al., 1991), at present no detailed analysis is available of all the possible interactions between transforming DNA and the $H$. polymorpha genome. Such information would open new ways for exploring the $H$. polymorpha genome. Furthermore, the availability of a general integration strategy would offer the possibility to routinely stabilize heterologous as well as homologous genes for gene expression purposes.

In order to improve the accessibility of $H$. polymorpha for molecular genetics, we adapted the transformation protocol described by Klebe et al. (1983) for $S$. cerevisiae, for transformation of $H$. polymorpha. A number of vectors was constructed which basically consist of a pBR322 replicon, an antibiotic resistance marker for $E$. coli and the $S$. cerevisiae $L E U 2$ gene, which functionally complements the $H$. polymorpha leu1.1 mutation (Gleeson et al., 1986). Here we report the high frequency transformation and autononomous replication of these plasmids and, when linearized within genomic sequences, their targeted integration into the genome with varying frequencies. Integrations were consistent with classical homologous single or double cross-over recombinations. Furthermore, evidence is presented for nonrecombinational repair of double-strand breaks in transforming plasmid DNA.

\section{Methods}

Strains and plasmids. These are listed in Table 1.

Cultivation media and growth conditions. Escherichia coli strains were grown in minimal M9 medium or rich LB medium (Sambrook et al., 1989). When necessary, media were supplemented with ampicillin (Ap; $100 \mu \mathrm{g} \mathrm{ml}^{-1}$ ) or erythromycin (Em; $150 \mu \mathrm{g} \mathrm{ml}^{-1}$ ). H. polymorpha strains were grown on selective minimal YND, YNG or YNM media $[0.7 \%$ yeast nitrogen base without amino acids supplemented with $2 \%$ $(\mathrm{w} / \mathrm{v})$ glucose, $2 \%(\mathrm{v} / \mathrm{v})$ glycerol or $0.5 \%(\mathrm{v} / \mathrm{v})$ methanol, respectively] or nonselective YPD medium $[1 \%(\mathrm{w} / \mathrm{v})$ yeast extract, $2 \%(\mathrm{w} / \mathrm{v})$ peptone and $2 \%(\mathrm{w} / \mathrm{v})$ glucose].

(Bio)chemicals. Chemicals used were of analytical grade and, unless stated otherwise, obtained from Merck. Restriction and DNAmodifying enzymes were used as recommended by the manufacturers (Boehringer Mannheim, Pharmacia and Biolabs).

DNA techniques and transformation of $E$. coli. Large-scale and mini preparations of plasmid DNA from $E$. coli were obtained by the alkaline lysis method (essentially as described by Ish-Horowicz \&

Table 1. Strains and plasmids used in this study

\begin{tabular}{|c|c|c|}
\hline & Relevant properties & Source or reference \\
\hline \multicolumn{3}{|l|}{ E. coli } \\
\hline $\mathrm{C} 600$ & supE44 hsdR thi-1 thr-1 leuB6 lacY1 tonA21 & Laboratory collection \\
\hline MC1061 & hsdR mcrB araD139 $\triangle($ araABC-leu $) 7679 \triangle$ lacX74 galU galK rpsL (Str $\left.{ }^{\mathrm{r}}\right)$ thi & Meissner et al. (1987) \\
\hline DHl & supE44 hsdR17 recAl endAl gyrA96 thi-I relAI & Hanahan (1983) \\
\hline \multicolumn{3}{|l|}{ H. polymorpha } \\
\hline Al6 & leul.1 derivative of CBS4732 & Veale et al. (1992) \\
\hline \multicolumn{3}{|l|}{ Plasmids } \\
\hline pHP7 & $\mathrm{Cm}^{\mathrm{r}} \mathrm{Em}^{\mathrm{r}}$, lac $\mathrm{Z} \alpha$ (derived from $\mathrm{pUC9}$ ) & Laboratory collection \\
\hline pHIP1 & $\mathrm{Em}^{\mathrm{r}}, L E U 2$, derivative of $\mathrm{pHP} 7$ & This work \\
\hline pHIP3 & $\mathrm{Em}^{\mathrm{r}}, L E U 2$, derivative of $\mathrm{pHP} 7$ & This work \\
\hline pHIP11 & pHIP $1+800$ bp fragment from $H$. polymorpha AO gene & This work \\
\hline pHRP2 & $\mathrm{Ap}^{\mathrm{r}}, L E U 2, H A R S I$ & This work \\
\hline pHIP111 & $\mathrm{Ap}^{r}, L E U 2, A M O$ gene preceded by $p \mathrm{AO}$ & This work \\
\hline pHIP112 & pHIP111 $+0.7 \mathrm{~kb} 3^{\prime}$ region of $\mathrm{AO}$ gene & This work \\
\hline
\end{tabular}


Burke, 1979) or the boiling method (essentially as described by Holmes \& Quigley, 1981), respectively. Plasmid DNA from $H$. polymorpha, used for retransformation of $E$. coli, was isolated as described by Hoffman \& Winston (1987), including phenol/chloroform and chloroform extraction and a final ethanol-precipitation step. Precipitated DNA was dissolved in $5 \mu 1 \mathrm{H}_{2} \mathrm{O}$ and dialysed against $\mathrm{H}_{2} \mathrm{O}$ for at least $1 \mathrm{~h}$, using a Millipore $0.025 \mu \mathrm{m}$ filter. Chromosomal DNA was isolated from $H$. polymorpha essentially as described by Sherman et al. (1986). Total DNA of transformants was separated on $0.8 \%$ agarose gels and after electrophoresis stained with ethidium bromide. Southern blot hybridization analysis was performed essentially as described by Southern (1975); DNA probes were labelled using the random primed labelling kit from Boehringer Mannheim in combination with $\left[\alpha^{-32} \mathrm{P}\right] \mathrm{dATP}$ from Amersham. Relative amounts of radioactivity (Southern blot experiments) were estimated by densitometer scanning with an LKB Ultroscan XL enhanced laser densitometer. Other DNA techniques were performed as documented (Sambrook et al., 1989).

$E$. coli strains C600 and DH1 were transformed with plasmid DNA according to the $\mathrm{CaCl}_{2}$ procedure described by Sambrook et al. (1989). Electrocompetent cells from $E$. coli strain MC1061 were prepared according to Dower et al. (1988) and electroporated with plasmid DNA isolated from $H$. polymorpha, using a Biorad Gene Pulser $(25 \mu \mathrm{F}, 2.5 \mathrm{kV}$ and $200 \mathrm{ohm}$ ).

Transformation of $H$. polymorpha. $H$. polymorpha strain Al6 was transformed by a modification of the method published by Klebe et al. (1983). A starter culture was prepared by inoculating a single colony (from a $1-2 \mathrm{~d}$ old YPD plate) into YPD medium $(10 \mathrm{ml}$ in a $50 \mathrm{ml}$ Erlenmeyer flask) followed by overnight incubation at $37^{\circ} \mathrm{C}$ in a rotary shaker at 300 r.p.m. Subsequently, cells were diluted into $100 \mathrm{ml}$ of fresh YPD medium at an $\mathrm{OD}_{600}$ of 0.1 and cultivated to an $\mathrm{OD}_{600}$ of $0.5-0.8$, harvested, washed in $50 \mathrm{ml}$ of solution A [1.0 M-sorbitol, $10 \mathrm{~mm}$-bicine $(\mathrm{pH} 8.35)$ and $3 \%(\mathrm{v} / \mathrm{v})$ ethylene glycol] and finally resuspended in $4 \mathrm{ml}$ of solution A supplemented with fresh $5 \%(\mathrm{v} / \mathrm{v})$ dimethyl sulphoxide (DMSO). It is essential to use DMSO from a fresh stock or DMSO stored at $-80^{\circ} \mathrm{C}$, because oxidized DMSO completely blocks transformation of $H$. polymorpha. Finally, $0.2 \mathrm{ml}$ aliquots of competent cells were quickly frozen in liquid nitrogen and stored at $-80^{\circ} \mathrm{C}$.

For each transformation, $0 \cdot 1-10 \mu \mathrm{g}$ plasmid DNA and $40 \mu \mathrm{g}$ of carrier DNA (presence of sonified and denatured salmon sperm DNA stimulated transformation frequencies approximately two- to threefold) in a total volume of $20 \mu \mathrm{l}$ was added to an aliquot of frozen competent cells. The mixture was thawed at $37^{\circ} \mathrm{C}$ for $5 \mathrm{~min}$ with occasional mixing, diluted with $1.5 \mathrm{ml}$ of solution B [40\% (w/v) PEG (Roth, Karlsruhe, FRG) and 200 mM-bicine (pH 8.35)] and incubated at $30^{\circ} \mathrm{C}$ for $1 \mathrm{~h}$ with occasional mixing. Subsequently, cells were centrifuged $(5 \mathrm{~min}$ at $3000 \mathrm{~g}$ ), washed in $1.5 \mathrm{ml}$ solution $\mathrm{C}$ [150 mM$\mathrm{NaCl}$ and $10 \mathrm{~mm}$-bicine ( $\mathrm{pH} 8.35)]$ centrifuged again and resuspended in $0.2 \mathrm{ml}$ of solution $\mathrm{C}$. Finally, appropriate dilutions (in solution $\mathrm{C}$ ) were plated on YND plates, which were incubated for $3-4 d$ at $37^{\circ} \mathrm{C}$. In general, cell viability (colony-forming ability) at the end of the complete procedure (preparation of competent cells and transformation) amounted to $40 \%$. Reversion frequency of the leul.1 mutation was always less than $10^{-7}$.

\section{Results}

Transformation with circular plasmids lacking sequence homology with the $H$. polymorpha genome

Using the optimized transformation protocol, several independent transformation experiments were carried out with plasmids pHIP3 and its derivative pHIP1 (Fig.
1), which to our knowledge at that time did not contain any $H$. polymorpha autonomous replicating sequence $(H A R S)$. As a control, transformations were also performed with the replicating plasmid pHRP2 (Fig. 1), which contains the HARSI sequence (Roggenkamp et al., 1986). Surprisingly, the plasmids pHIP1 and pHIP3 transformed the yeast with slightly higher frequencies than the replicating plasmid pHRP2 (Fig. 2). At an input of $1 \mu \mathrm{g}$ plasmid DNA (per aliquot of competent cells), transformations by $\mathrm{pHIP} 1$ and $\mathrm{pHIP} 3$ resulted in approximately $5 \times 10^{3}$ transformants, suggesting the establishment of the plasmids as autonomous elements in the host.

Conclusive evidence for autonomous behaviour was provided by three observations. Firstly, the plasmids could be rescued intact from $H$. polymorpha by electrotransformation of $E$. coli with total yeast DNA (results not shown). Secondly, segregational instability of the $\mathrm{Leu}^{+}$phenotype was observed. After 40 generations of non-selective growth (YPD medium), $55-85 \%$ of the cells had lost the $\mathrm{Leu}^{+}$trait. Thirdly, Southern hybridization analyses showed that the plasmids were maintained as multimers.

Fig. 3 (lanes 1-4) shows the result of a Southern hybridization experiment in which both unrestricted and restricted DNA from a representative pHIP3 transformant (T2, grown for 40 generations in selective medium) was probed with pHIP3. Distinct hybridization signals (lane 2) above and below the position of unrestricted chromosomal DNA were observed. The higher signals matched with discrete bands visible on ethidiumbromide-stained agarose gels. Digestion of total DNA with an enzyme ( $B g l \mathrm{II}$; lane 3 ) having no recognition site in the plasmid DNA did not alter the position of these bands, whereas restriction with $N c o$ I (lane 4), which linearizes pHIP3, shifted the signals completely to the position of linear pHIP3 $(5.8 \mathrm{~kb})$. These results clearly indicate that plasmid pHIP3 is maintained autonomously in $H$. polymorpha as a circular molecule. Similar results were obtained with pHIP1 (results not shown). Berardi \& Thomas (1990) recently presented evidence for the existence of an $H$. polymorpha replicon-like sequence within or near the coding regions of the $S$. cerevisiae $L E U 2$ gene. Conceivably, this $S$. cerevisiae-derived $A R S$ is responsible for the autonomous behaviour of plasmids pHIP1 and pHIP3 in $H$. polymorpha.

Further information about the fate of plasmid pHIP3 after transformation into $H$. polymorpha was obtained by Southern hybridization analyses of nine independent pHIP3 transformants (the analysis of five representative transformants is shown in Fig. 4). BglII-treated DNAs (lanes $1,4,7,10,13$ ) mainly showed high-molecular-mass bands of varying lengths, indicating the presence of different multimeric forms of pHIP3 in the transformants. As expected, NcoI digestion of DNAs from the 

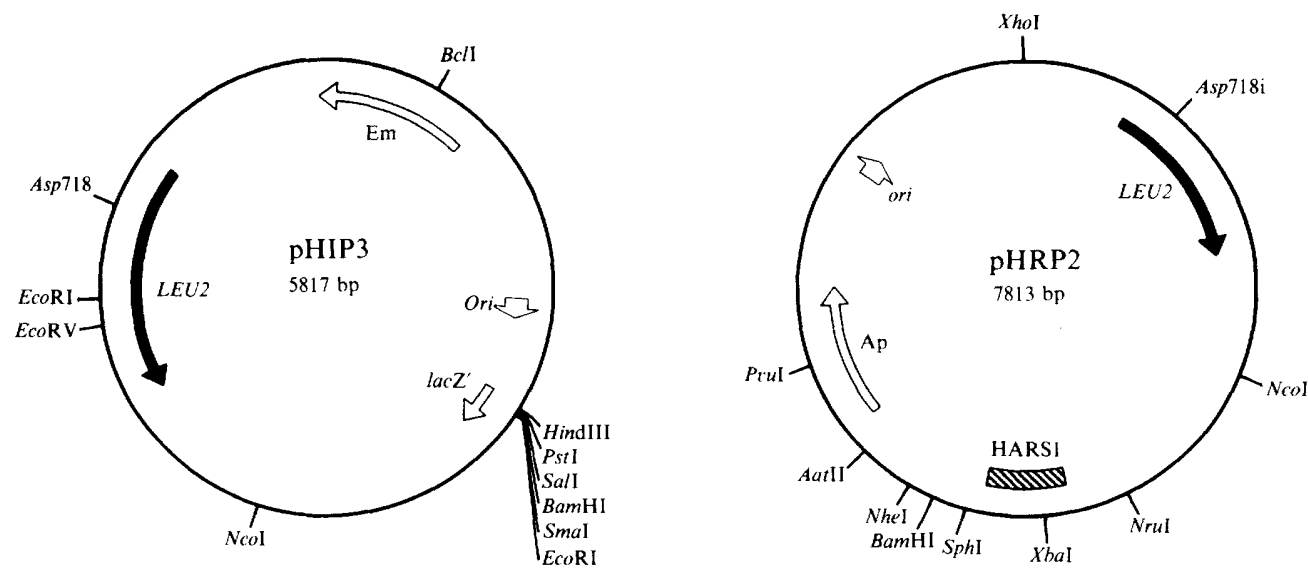

Fig. 1. Physical maps of the E. coli-H. polymorpha shuttle vectors pHIP3 and pHRP2. Plasmid pHIP3 was constructed from plasmid pHP7, consisting of the 1630 bp AhaIII-AatII fragment from pUC9 (nucleotides 2620-1570; Yanisch-Perron et al., 1985), the 960 bp SacI-ClaI fragment from pE194 (nucleotides 1940-2900; Horinouchi \& Weisblum, 1982a) carrying the Em ${ }^{\mathrm{r}}$ gene and the $1030 \mathrm{bp}$ HpalI - MboI fragment from pC194 (nucleotides 975-2005; Horinouchi \& Weisblum, 1982b) carrying a Cm ${ }^{\mathrm{r}}$ gene. Plasmid pHIP3 was constructed by insertion of the $2 \cdot 2 \mathrm{~kb} \mathrm{SalI-XhoI} \mathrm{fragment} \mathrm{(sites} \mathrm{were} \mathrm{filled} \mathrm{in)} \mathrm{from} \mathrm{YEp13} \mathrm{(Broach} \mathrm{et} \mathrm{al.,} \mathrm{1979),} \mathrm{containing} \mathrm{the}$ $S$. cerevisiae LEU2 gene, into the StuI site of $\mathrm{pHP} 7$, thereby inactivating the $\mathrm{Cm}^{r}$ gene. Plasmid $\mathrm{pHIP} 1$ is identical to $\mathrm{pHIP} 3$ except for the location of the $L E U 2$ gene, which was inserted into the SalI site of pHP7. Plasmid pHRP2 was constructed by inserting the $L E U 2$ containing SalI-Xhol fragment from YEp13 (Broach et al., 1979) into StuI- and Smal-digested pHARS1 (Roggenkamp et al., 1986), thereby inactivating the URA3 gene. Complete sequences of plasmids pHIP3 and pHRP2 are available from the authors on request.

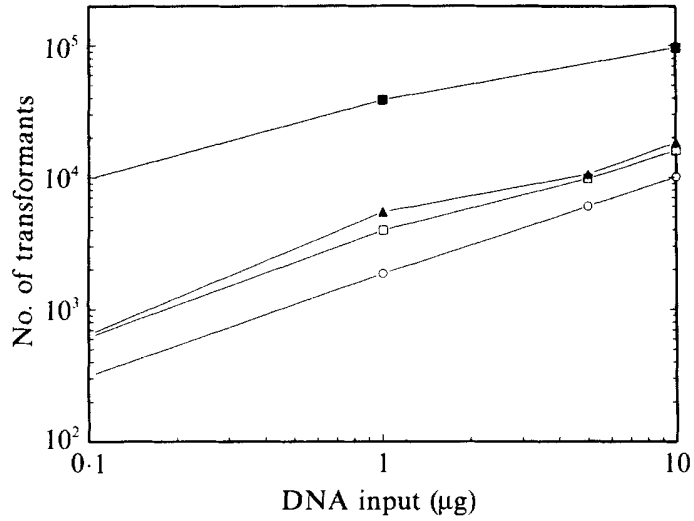

Fig. 2. Transformation of H. polymorpha A16 (leul.l) with different plasmids. Cells were treated with different amounts of plasmid DNA $(0 \cdot 1,1 \cdot 0,5 \cdot 0$ and $10 \cdot 0 \mu \mathrm{g})$ using the optimized transformation protocol described in Methods. Transformation frequencies are mean values of at least three independent transformation experiments and are given as the total number of $\mathrm{Leu}^{+}$transformants obtained per $0.2 \mathrm{ml}$ of competent cells. O, pHRP2; $\square$, pHIP1; $\mathbf{\Delta}$, pHIP3; $\mathbf{0}$, pHIP1 linearized with BamHI.

transformants (lanes $2,5,8,11,14$ ) resulted in signals of the size of linear pHIP3, $5.8 \mathrm{~kb}$. From this it can be concluded that the plasmids replicate as multimers, consisting of a variable number of monomers connected in a head-to-tail configuration. Three transformants (T2, T3 and T4) gave single bands, implying that they only contain intact copies of the plasmid. Two transformants contained additional bands smaller ( $\mathrm{T} 1: 3.7 \mathrm{~kb}$, lane 2$)$ or larger (T5: $7.0 \mathrm{~kb}$, lane 14$)$ than the original plasmid.

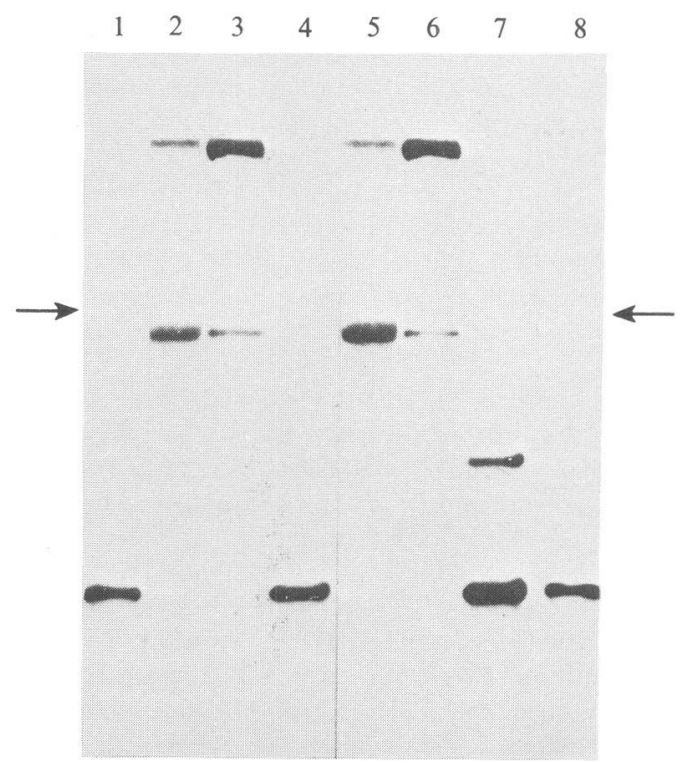

Fig. 3. Southern hybridization analysis of total DNA of pHIP3 transformant T2. Undigested (lanes 2 and 5), BglII-digested (lanes 3 and 6) and NcoI-digested (lanes 4 and 7) total DNA of pHIP3 transformant T2 and NcoI-digested pHIP3 DNA isolated from $E$. coli (lanes 1 and 8 ) was probed with pHIP3 (lanes 1-4) or a recombinant probe containing $1 \mathrm{~kb}$ of plasmid pHIP3 and $1 \mathrm{~kb}$ of the genomic (single copy) AO gene (lanes 5-8). Arrows indicate the position of undigested chromosomal DNA.

Restriction with Asp 718i (lanes 3,6,9,12, 15), which also linearizes pHIP3, resulted in a reverse situation: $\mathrm{T} 1$ showed a signal above $(9.5 \mathrm{~kb}$, lane 3$)$ and $\mathrm{T} 5$ a signal below $(1 \cdot 1 \mathrm{~kb}$, lane 15$)$ the position of linear pHIP3. The 


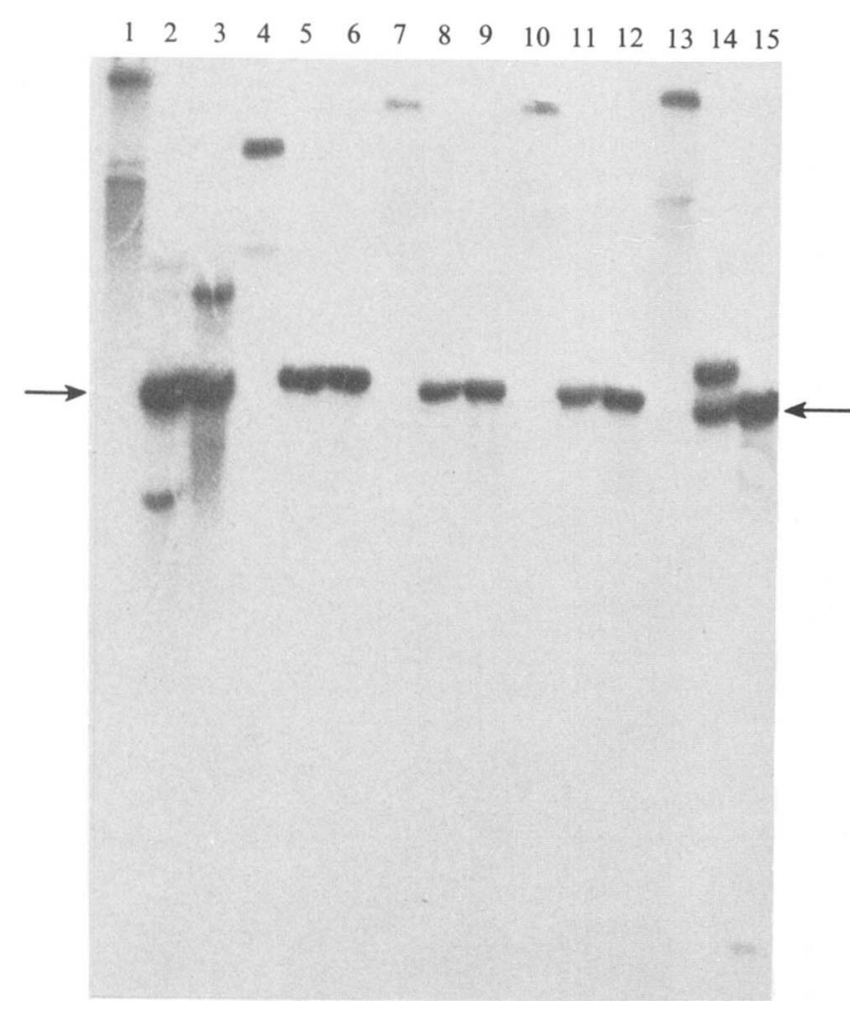

Fig. 4. Southern hybridization analysis of total DNAs of pHIP3 transformants T1-T5. BglII- (lanes 1, 4, 7, 10, 13), NcoI- (lanes 2, 5, 8, 11,14) and Asp 718i- (lanes 3, 6, 9, 12,15) digested DNAs of T1 (lanes 1, 2, 3), T2 (lanes 4, 5, 6), T3 (lanes 7, 8, 9), T4 (lanes 10,11, 12) and T5 (lanes 13, 14, 15) were probed with plasmid pHIP3. The arrow indicates the position of linear pHIP3 $(5.8 \mathrm{~kb})$.

only structure that could account for the patterns of $\mathrm{T} 1$ and $\mathrm{T} 5$ is a multimer in which one of the monomers contains a deletion encompassing the $A s p 718 \mathrm{i}$ or the $N c o$ I site, respectively. The sizes of the additional signals with $\mathrm{T} 1$ and $\mathrm{T} 5$ are consistent with deletions of $2 \cdot 1 \mathrm{~kb}$ and $4.7 \mathrm{~kb}$, respectively.

To determine the approximate copy number of the plasmids in $H$. polymorpha, the original probe from the Southern blot shown in Fig. 3 lanes 1-4 (transformant T2) was removed and the blot was reprobed with a fragment consisting of approximately $1 \mathrm{~kb}$ of pHIP3 (Cm moiety) and $1 \mathrm{~kb}$ of $H$. polymorpha genomic DNA (part of the AO gene). Densitometric scanning of the signals representing linear pHIP3 and the genomic fragment (Fig. 3, lane 7) revealed an approximate copy number of 6 (plasmid copies per genome equivalent).

\section{Targeted integration of plasmids in the H. polymorpha genome}

In order to examine the possibility of integrating plasmids in the $H$. polymorpha genome at defined sites, three plasmids were constructed (Fig. 5a). Plasmid
Table 2. Targeted integration of plasmids in H. polymorpha

Targeted integration frequencies of plasmids pHIP11 and pHIP112 were determined by screening for the $\mathrm{Mut}^{-}$phenotype. Targeted integration frequency of pHIP111 was determined by Southern hybridization analysis. For detailed information, see text. Frequencies are given as the number of integrants among the total number of transformants tested. ND, Not determined.

\begin{tabular}{lcc}
\hline \hline \multicolumn{1}{c}{ Plasmid used } & $\begin{array}{c}\text { Site-directed } \\
\text { integration frequency }\end{array}$ & Percentage \\
\hline pHIP11 circular & $0 / 550$ & 0 \\
pHIP11 linear $($ BglII) & $5 / 543$ & $1 \cdot 0$ \\
pHIP112 circular & $0 / 300$ & 0 \\
pHIP112 linear $($ BamHI) & $9 / 300$ & $3 \cdot 0$ \\
pHIP111 circular & ND & - \\
pHP111 linear $($ SphI $)$ & $2 / 9$ & $22 \cdot 2$ \\
\hline \hline
\end{tabular}

pHIP11, carrying a $0.8 \mathrm{~kb}$ internal part of the $H$. polymorpha AO gene, is expected to integrate in the AO coding region by a single cross-over recombination event (also called 'homologous additive integration'; Hinnen et al., 1978), thereby disrupting the AO gene (Fig. $5 b$ ). Plasmid pHIP112, carrying the homologous amine oxidase gene (AMO) downstream of the AO promoter $(2.3 \mathrm{~kb}$ region) and in addition a $0.7 \mathrm{~kb}$ fragment covering the $3^{\prime}$ end of the $\mathrm{AO}$ gene, was designed to replace the complete AO structural gene by a double cross-over recombination event (Fig. $5 d$ ). Finally, plasmid pHIP111, carrying the $H$. polymorpha $\mathrm{AO}$ promoter on a $2.3 \mathrm{~kb}$ fragment, was expected to integrate in the $\mathrm{AO}$ promoter region in an additive way, thereby leaving the $\mathrm{AO}$ coding region intact and placing the plasmid-borne AMO under control of one of the copies of the AO promoter (Fig. $5 f$ ).

In S. cerevisiae (Orr-Weaver et al., 1981) linear ends of homologous sequences are recombinogenic and are used to target plasmids to specific sites on the genome. To test this for $H$. polymorpha, plasmids were linearized within the regions homologous to the yeast genome (integration boxes). Plasmid pHIP11 was linearized (BglII) in the middle of its $800 \mathrm{bp}$ integration box, pHIP112 was cut at the $B a m H I$ site, thereby exposing its 2.3 and $0.7 \mathrm{~kb}$ integration boxes, and pHIP111 was cut at the $S p h I$ site, thereby creating recombining regions of 0.5 and $1.8 \mathrm{~kb}$. In all three cases, linearization of the plasmids increased the transformation frequency approximately 10-fold, resulting in frequencies of approximately $10^{4}$ transformants per $\mu \mathrm{g}$ DNA. To determine the frequency of targeted integration of pHIP11 and pHIP112, which should lead to disruption of the AO gene, transformants were screened for their inability to utilize methanol as sole carbon source. As shown in Table 2, 1 and $3 \%$ of the linear pHIP11 and pHIP112 transformants, respectively, displayed a $\mathrm{Mut}^{-}$(methanol utilization defective) phenotype, whereas no $\mathrm{Mut}^{-}$phenotype was observed 
(a)

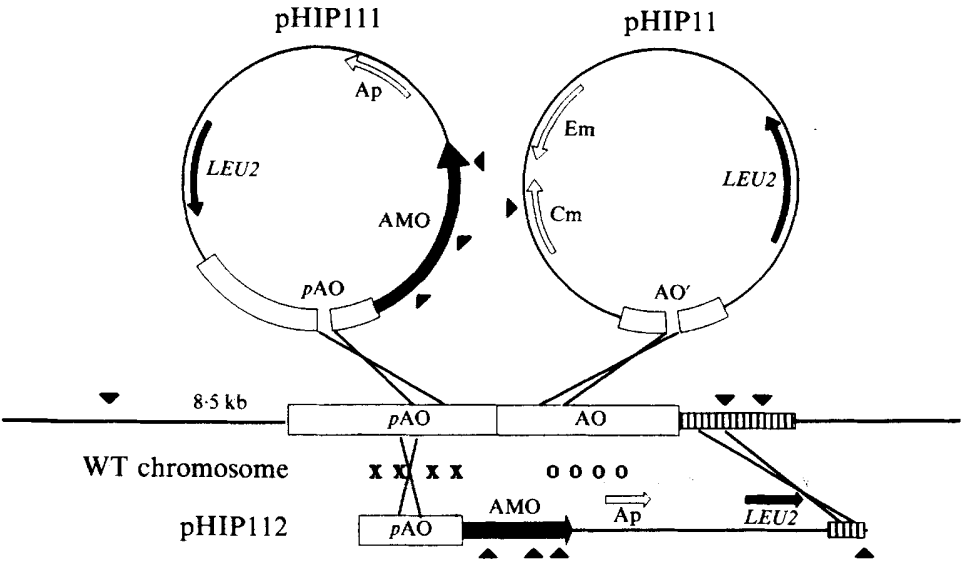

(b)

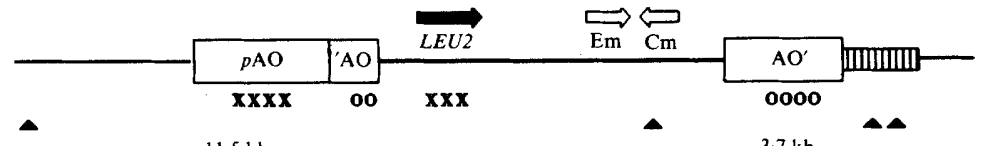

(c)
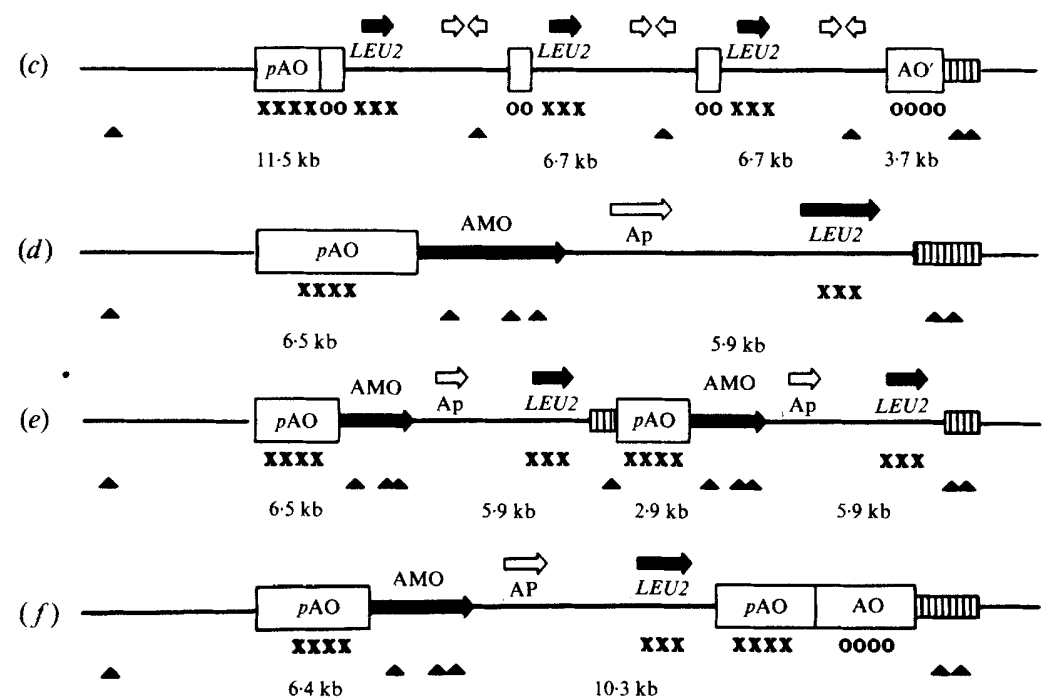

Fig. 5. (a) Physical maps of integrating plasmids pHIP11, pHIP111 and pHIP112 and the structure of the relevant part of the

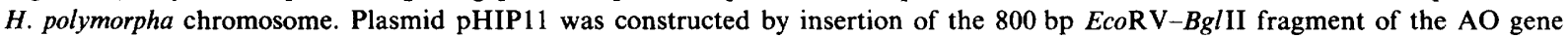
(nucleotides 22-823; Ledeboer $\mathrm{et} \mathrm{al.,} \mathrm{1985)} \mathrm{into} \mathrm{BamHI-} \mathrm{and} \mathrm{SmaI-digested} \mathrm{pHIP1.} \mathrm{Plasmids} \mathrm{pHIP111} \mathrm{and} \mathrm{pHIP112} \mathrm{are} \mathrm{derivatives} \mathrm{of}$ plasmid pTZ19R (Mead et al., 1986). pHIP111 was constructed by insertion of the $2 \cdot 2 \mathrm{~kb}$ SalI-XhoI fragment (XhoI site filled in) from YEp13 (Broach et al., 1979), containing the S. cerevisiae LEU2 gene into SalI-HindIII- (HindIII site filled in) cleaved pTZ19R, resulting in plasmid pTZ19LEU. Subsequently, two fragments were simultaneously inserted into BamHI/SacI-digested pTZ19LEU: (i) a $2 \cdot 2 \mathrm{~kb}$ BamHI-HindIII fragment containing the AO promoter region (Ledeboer et al., 1985) in which the AO translation initiation codon was replaced by a HindIII site by means of site-directed mutagenesis; and (ii) a $2.2 \mathrm{~kb}$ HindIII-SacI fragment containing the $H$. polymorpha amine oxidase (AMO) gene (nucleotides -18 to +2138 ; Bruinenberg et al., 1989). Plasmid pHIP112 was constructed by insertion of a $0.7 \mathrm{~kb} \mathrm{Bg} / \mathrm{II}-\mathrm{XbaI}$ fragment (BglII site filled in) covering the $3^{\prime}$ region of the AO gene (nucleotides 1904 to 2604; Ledeboer $e t$ al., 1985) into Sal I/XbaI- ( $\mathrm{SalI}$ site filled in) cleaved pHIP111. Complete sequences of plasmids pHIP11, pHIP111 and pHIP112 are available from the authors on request. $(b-f)$ Chromosomal structures resulting from homologous recombination. (b) Chromosomal structure resulting from $1 \times$ cross-over recombination of one copy of pHIP11 within the genomic AO gene. (c) Chromosomal structure resulting from $1 \times$ cross-over recombination of three copies of pHIP11 within the genomic AO gene. (d) Chromosomal structure resulting from $2 \times$ cross-over recombination of pHIP112 with the flanking regions of the genomic AO gene (gene replacement). (e) Chromosomal structure resulting from $2 \times$ cross-over recombination of pHIP112 with the flanking regions of the genomic AO gene (gene replacement), followed by $1 \times$ cross-over recombination of an additional plasmid copy. $(f)$ Chromosomal structure resulting from $1 \times$ cross-over recombination of one copy of pHIP111 within the promoter region of the genomic AO gene. Small arrowheads $(\Delta$ or $\nabla)$ indicate $\mathrm{NcoI}$ cleavage sites, $\mathrm{kb}$ values indicate the sizes of the $\mathrm{NcoI}$ fragments detected in Southern hybridization analyses with an internal $\mathrm{AO}$ probe $(\mathrm{OOOO})$ or a recombinant probe homologous to the $\mathrm{AO}$ promoter region $(\mathrm{pAO})$ and the plasmid-borne $L E U 2$ gene $(\mathrm{xxxx})$. The box with vertical hatching represents the region downstream of the $\mathrm{AO}$ gene. 'AO and $\mathrm{AO}^{\prime}$ indicate 5'-or 3'-deleted $\mathrm{AO}$ regions, respectively. Small open boxes in $(c)$ represent duplicated ' $A O^{\prime}$ regions. Different chromosomal structures are not drawn to scale. 


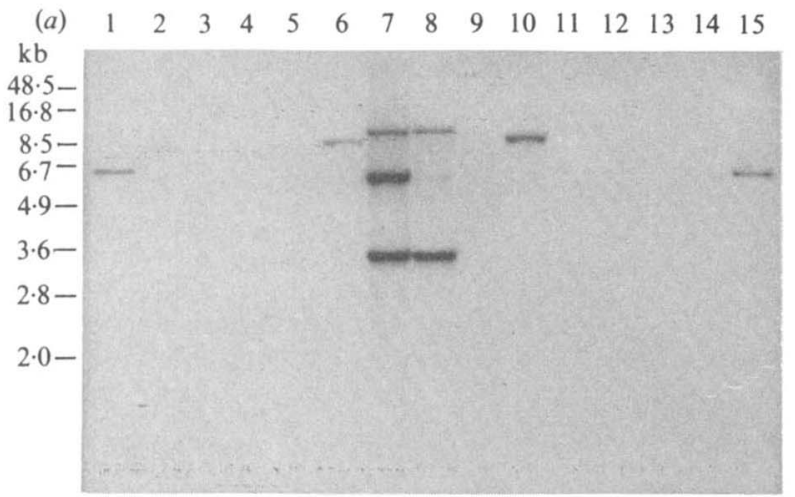

(b) $\begin{array}{lllllllllllllll}1 & 2 & 3 & 4 & 5 & 6 & 7 & 8 & 9 & 10 & 11 & 12 & 13 & 14 & 15\end{array}$

Fig. 6. Southern hybridization analyses of DNAs from chromosomally engineered strains. NcoI-digested DNAs of E. coli-derived plasmids pHIP1I (lanes 1, 15), pHIP111 (lane 2), pHIP112 (lane 3), H. polymorpha strain A16 (lane 6), transformants 11 a and $11 \mathrm{~b}$ (lanes 7,8 ), 111 (lane 10) and $112 \mathrm{a}$ and $112 \mathrm{~b}$ (lanes 11, 12) were hybridized with an internal part of the AO gene (panel $a ; 1260$ bp PvuI-NdeI fragment of the $\mathrm{AO}$ gene, indicated as $000 \mathrm{O}$ in Fig. 5) or a recombinant probe homologous to $1.5 \mathrm{~kb}$ of the AO promoter region and $1.1 \mathrm{~kb}$ of the plasmid-borne $L E U 2$ gene (panel $b$; indicated as XXXX in Fig. 5). Lanes 4, 5, 9, 13 and 14 contained molecular mass markers which did not hybridize with the probes used.

among transformants resulting from circular plasmid DNA. These results emphasize the significance of linearizing the plasmids within their integration boxes. They also suggest that, analogous to $S$. cerevisiae, plasmids can be targeted to specific sites in the genome of $H$. polymorpha by linearization within homologous regions. When the $\mathrm{Mut}^{-}$transformants were grown on glycerol, conditions which partially derepress AO synthesis, no alcohol oxidase activity could be detected in these cells, confirming disruption of the $\mathrm{AO}$ gene. This was corroborated by Southern hybridization analysis (Fig. 6) of total DNAs isolated from untransformed yeast (A16), two pHIP11 transformants (11a and b) and two pHIP112 transformants (112a and b). DNAs were digested with $\mathrm{NcoI}$, hybridized first with an internal AO fragment (Fig. 6a), and, after removing the first probe, with a fragment containing part of the $\mathrm{AO}$ promoter and part of the plasmid-borne LEU2 gene ( $p \mathrm{AO} / L E U 2$ probe; Fig. $6 b$ ).

Hybridization of A16 with the AO probe showed a band of approximately $8.5 \mathrm{~kb}$ (Fig. $6 a$, lane 6), revealing the position of the unknown NcoI site upstream of the AO gene. DNAs from $11 \mathrm{a}$ and $11 \mathrm{~b}$ showed bands of 3.7 and $11.5 \mathrm{~kb}$ (Fig. $6 a$, lanes 7 and 8 ), which is consistent with single cross-over recombinations within the $\mathrm{AO}$ gene as depicted in Fig. 5(b). In addition, DNA from 11 a (lane 7) showed a band of $6.7 \mathrm{~kb}$, at the same position as linear pHIP11 (lanes 1 and 15), indicating tandem integrations of pHIP11 (Fig. 5c). Reprobing the DNAs with the $p \mathrm{AO} / L E U 2$ probe further confirmed the chromosomal structures of $11 \mathrm{a}$ and $11 \mathrm{~b}$; only the bands representing linear pHIP11 and the chromosomal fragment covering the AO $5^{\prime}$ region reappeared (Fig. $6 b$, lanes 7 and 8). The relative density of the band representing linear DNA in case of $11 \mathrm{a}$ indicates tandem integration of three plasmid copies.

As expected, hybridization of DNAs from 112a and $112 \mathrm{~b}$ with the AO probe (Fig. $6 a$, lanes 11 and 12 ) showed no signals, indicating replacement of the AO gene by the plasmid. This was confirmed by reprobing the DNAs with the $p A O X / L E U 2$ probe. Bands of approximately 6.5 and $5.9 \mathrm{~kb}$ appeared (Fig. $6 b$, lanes 11 and 12), which is consistent with the gene-replacement structure depicted in Fig. 5(d). In addition, 112a showed a band of $2.9 \mathrm{~kb}$, which is at the same position as the $2.9 \mathrm{~kb}$ pHIP112 fragment visible in lane 3 . This additional fragment can be explained by the chromosomal structure depicted in Fig. 5(e). This structure could result from a gene-replacement recombination followed by a single cross-over recombination of an additional (recircularized) plasmid copy.

Since site-specific integration of pHIP111 leaves the AO gene intact, integrations could not be screened by a Mut $^{-}$phenotype, and therefore had to be analysed directly by Southern blot hybridization analysis. Out of nine transformants analysed, two showed identical hybridization patterns consistent with single cross-over recombinations in the promoter region of the $\mathrm{AO}$ gene. Hybridization of NcoI-digested DNA from one of these pHIP111 integrants with the AO probe (Fig. 6a, lane 10), showed a band of $10.3 \mathrm{~kb}$, representing the $N c o I$ fragment at the right-hand side of the chromosomal structure depicted in Fig. 5(f). Reprobing the DNA with the $p \mathrm{AO} / L E U 2$ probe resulted in bands of 10.3 and $6.4 \mathrm{~kb}$ (Fig. 6h, lane 10), representing the right- and lefthand NcoI fragments of the predicted chromosomal structure, respectively. The relative intensities of the bands are also consistent with this structure: the 
Table 3. Transformation of $H$. polymorpha with linearized plasmids

$H$. polymorpha strain A16 was transformed with circular and linearized pHIP1 and pHIP11 at a DNA input of $0 \cdot 1 \mu \mathrm{g}$. Linear DNA was used immediately after digestion without further purification. Circular DNA was treated in the same way as linear DNA except for the addition of the restriction enzyme. Transformation frequencies are given as an absolute value (total number

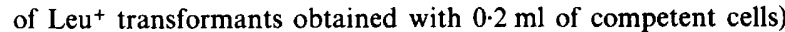
and a relative value (related to the frequency obtained with circular plasmid DNA). Transformation frequencies are mean values of three independent transformation experiments.

\begin{tabular}{llcr}
\hline \hline Plasmid used & $\begin{array}{c}\text { Location of } \\
\text { linearizing cut }\end{array}$ & $\begin{array}{c}\text { No. of } \\
\text { transformants }\end{array}$ & $\begin{array}{c}\text { Relative } \\
\text { frequency }\end{array}$ \\
\hline pHIP1 & & & \\
Circular & - & 620 & $1 \cdot 0$ \\
BamHI $\left(5^{\prime}\right)^{*}$ & Vector & 9800 & $15 \cdot 7$ \\
NcoI $\left(5^{\prime}\right)^{*}$ & Vector & 9500 & $15 \cdot 1$ \\
SalI $\left(5^{\prime}\right)$ & Vector & 8800 & $14 \cdot 1$ \\
PstI $\left(3^{\prime}\right)^{*}$ & Vector & 7100 & $11 \cdot 5$ \\
SmaI (blunt)* & Vector & 5800 & $9 \cdot 4$ \\
Asp718i $\left(5^{\prime}\right)^{*}$ & LEU2 & 6400 & $10 \cdot 2$ \\
EcoRV $(\text { blunt })^{*}$ & LEU2 & 4100 & $6 \cdot 6$ \\
pHIP11 & & & \\
Circular & - & 310 & $1 \cdot 0$ \\
BglII $\left(5^{\prime}\right)^{*}$ & AO region & 4600 & $14 \cdot 8$ \\
NcoI $\left(5^{\prime}\right)^{*}$ & Vector & 5600 & $18 \cdot 0$ \\
\hline \hline
\end{tabular}

* Type of DSB (blunt ends, $3^{\prime}$ or $5^{\prime}$ overhanging ends).

$p \mathrm{AO} / L E U 2$ probe gave stronger hybridization signals with the right-hand fragment, containing both $p \mathrm{AO}$ and $L E U 2$, than with the left fragment (containing only $p \mathrm{AO}$ ). Transformants in which no homologous recombination had occurred (seven out of nine) appeared to contain intact autonomous plasmids capable of retransforming $E$. coli (results not shown).

In order to test the stability of the integrated plasmids, transformant strains were grown under non-selective conditions for 40 generations, and the percentage of $\mathrm{Leu}^{+}$cells per culture was determined as described in Methods. All transformants showed $100 \%$ stability of the $\mathrm{Leu}^{+}$phenotype, indicating stable maintenance of the plasmids in the genome. Transformants in which the AO gene was disrupted also showed full stability of the $\mathrm{Mut}^{-}$ phenotype.

\section{Repair of double-strand breaks in plasmid DNA}

Targeted integration of linear plasmids pHIP11, pHIP111 and pHIP112 only occurred in 1,3 or $22 \%$ of cases, respectively. This could be due to the presence of double-strand break (DSB) repair systems, which efficiently recircularize linear plasmids in a homologyindependent way (Orr-Weaver \& Szostak, 1983; Kunes et al., 1985; Perera et al., 1988), enabling the plasmids to replicate as autonomous elements. To test this, plasmid
pHIP1, which shares no sequence homology with the $H$. polymorpha genome, was linearized at different sites and used to transform strain A16 at a DNA input of $0 \cdot 1 \mu \mathrm{g}$. Table 3 shows that linearization of pHIP1 in its vector regions by enzymes creating $5^{\prime}$ overhanging ends increased the transformation frequencies approximately 15-fold as compared to circular pHIP1. At higher DNA input $(1$ to $10 \mu \mathrm{g})$, stimulation decreased approximately twofold (Fig. 2). This stimulatory effect of plasmid linearization will be considered in the Discussion. Further evidence for DSB repair was provided by transformations with pHIP1 linearized within the coding region of the selective $L E U 2$ gene (Asp718i). In this case, transformation frequencies amounted to approximately $68 \%$ of the corresponding value for pHIP1 linearized outside the LEU2 gene, indicating efficient and precise repair of the DSB in the $L E U 2$ gene. Furthermore, the results presented in Table 3 show that repair of $3^{\prime}$ overhanging or blunt DSB is slightly less efficient (77 and $63 \%$, respectively) than repair of $5^{\prime}$ overhanging DSB.

The above results clearly show that DSB in plasmid regions bearing no homology with chromosomal DNA are efficiently repaired in $H$. polymorpha. To determine whether this also occurs in the case of DSB at sites having homology with chromosomal DNA, and whether this takes place without interaction with the homologous chromosomal locus, linearized plasmid pHIP11 was used to transform strain A16 at a DNA input of $0 \cdot 1 \mu \mathrm{g}$. Transformation frequencies with pHIP11 linearized ( $B g l \mathrm{II})$ within the $0.8 \mathrm{~kb}$ region homologous to the genomic AO gene were not increased as compared to pHIP11 linearized within its nonhomologous vector region ( $N c o I$; Table 3), suggesting that the $B g l \mathrm{II}$ cut is repaired without interaction with the homologous region on the chromosome. Physical evidence for non-recombinational DSB repair was provided by Southern hybridization analysis of DNAs from eight linear pHIP11 transformants (Fig. 7). These transformants were all $\mathrm{Mut}^{+}$, indicating that pHIP11 had not integrated in the AO gene. DNAs from four $B g l \mathrm{II}-$ and four Ncol-linearized pHIP11 transformants were digested with $B g l \mathrm{II}$ or $\mathrm{Ncol}$. Hybridization with pHIP11 revealed that one out of four plasmid DNAs obtained from pHIP11-BglII transformants contained an intact $B g / \mathrm{II}$ site and three of four plasmid DNAs obtained from the pHIP11-NcoI transformants contained an intact $\mathrm{NcoI}$ site. This value of $50 \%$ precise repair is not significantly different from the $68 \%$ precise repair of DSB within the $L E U 2$ gene. Restriction of the plasmids lacking either the $B g l \mathrm{II}$ or the $N c o$ I site with $N c o$ I or $B g l \mathrm{II}$, respectively, resulted in signals at the position of linear intact pHIP11, indicating only small rearrangements encompassing the lost restriction site. 


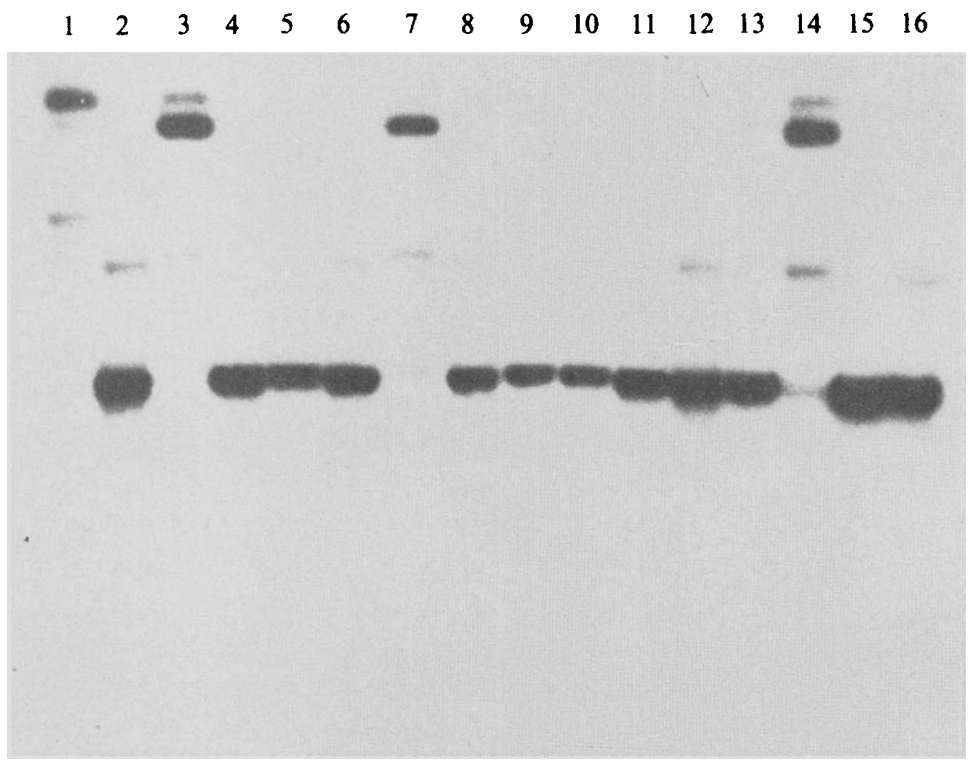

Fig. 7. Southern hybridization analyses of DNAs from linear pHIP11 transformants. BglII- (lanes with odd numbers) and NcoI- (lanes with even numbers) digested DNAs from four $B g l$ II-linearized pHIP11 transformants (lanes 1-8) and four NcoI-linearized pHIP11 transformants (lanes 9-16) were probed with pHIP1. The arrow indicates the position of linear pHIP11.

\section{Discussion}

In this paper we describe an optimized method for plasmid-mediated transformation of the methylotrophic yeast $H$. polymorpha and a successful strategy for targeted plasmid integration. Although plasmid transformations and plasmid integrations have been reported for $H$. polymorpha by several authors (Gleeson et al., 1986; Roggenkamp et al., 1986; Tikhomirova et al., 1986; Berardi \& Thomas, 1990; Sierkstra et al., 1991; Beburov et al., 1990; Hodgkins et al., 1990; Sudbery et al., 1988; Fellinger et al., 1991), no detailed analysis was available of the possible interactions between transforming DNA and the H. polymorpha genome. Because this information would greatly enhance the possibilities for genetic engineering of $H$. polymorpha, this study aimed to perform such an analysis.

The main advantage of our protocol over other protocols for transformation of $H$. polymorpha (Gleeson et al., 1986; Roggenkamp et al., 1986; Tikhomirova et al., 1986; Berardi \& Thomas, 1990) appeared to be its reproducibility. Very recently, a transformation protocol much resembling our protocol has been shown to be applicable to a variety of yeast species including $S$. cerevisiae and Schizosaccharomyces pombe (Dohmen et al., 1991). Using our protocol and the replicating plasmid pHRP2 (contains the HARS1 sequence; Roggenkamp et al., 1986), we were able to obtain highly reproducible transformation frequencies of $2 \times 10^{3}$ transformants per $\mu \mathrm{g}$ plasmid DNA. Recently, the use of this protocol and vector pHRP2 allowed us to generate $H$. polymorpha gene libraries in mutant strains which are impaired in the assembly of functional peroxisomes (Cregg et al., 1990).
Two genes involved in peroxisome assembly were successfully isolated from these gene libraries (P. Haima and others, unpublished results).

Surprisingly, transformation of $H$. polymorpha strain A16 with plasmids pHIP1 and pHIP3 lacking the $H A R S 1$ sequence resulted in approximately twofold higher frequencies. This is probably due to the presence of an active $H$. polymorpha replicon-like sequence within or near the coding regions of the $S$. cerevisiae LEU2 gene (Berardi \& Thomas, 1990). ARS activity conferred by the $S$. cerevisiae $L E U 2$ gene fragment has also been detected in Pichia pastoris (Cregg et al., 1985). Autonomous behaviour of the plasmids was confirmed by the observation that plasmids could be rescued intact from the yeast by retransformation of $E$. coli with total yeast DNA and by the instability of the $\mathrm{Leu}^{+}$trait under nonselective conditions. Southern hybridization analyses revealed that the plasmids replicated as multimers consisting of monomers in a head-to-tail configuration at an approximate copy number of 6 (monomers per genome equivalent). Two out of nine transformants analysed appeared to contain multimers in which one of the monomers contained a deletion. The nature of this structural instability is as yet unknown. Possible explanations include slipping of the recombination mechanism responsible for yielding multimers or structural instability of the multimeric plasmid forms. Plasmid multimerization was observed in $H$. polymorpha by Tikhomirova et al. (1986) and in Sch. pombe by Sakaguchi \& Yamamoto (1982), and was shown to enhance the mitotic stability of the plasmids. Conceivably, plasmid multimerization is responsible for the relatively high mitotic stability of the pHIP plasmids in 
H. polymorpha under non-selective growth conditions (frequency of plasmid loss is $55-85 \%$ per 40 generations) as compared to the stability of plasmids containing HARS1 and HARS2 sequences (plasmid loss for pHARS 1 and pHARS 2 amounts to $98 \%$ per 10 generations; Roggenkamp et al., 1986). A high degree of plasmid multimerization might also offer an explanation for the occurrence of stable phenotypes with multi-copy tandem arrangements of plasmid sequences as observed by Roggenkamp and coworkers in $H$. polymorpha pHARS1 and pHARS2 transformants (Roggenkamp et al., 1986; Janowicz et al., 1991). Although the authors favour multi-copy integration of the plasmids in the genome, the possibility of multimeric autonomous plasmids cannot be ruled out. Detailed Southern hybridization analyses of these stable transformants should clarify this point.

Targeted integration with plasmids pHIP11 and pHIP112 by single or double cross-over recombinations, respectively, was only observed with plasmids linearized within the regions homologous to the yeast genome (integration boxes). From this it may be concluded that, analogous to $S$. cerevisiae (Orr-Weaver et al., 1981) and $P$. pastoris (Cregg \& Madden, 1987), linear ends of homologous sequences are recombinogenic. However, targeted integration of circular plasmids has also been observed in $H$. polymorpha (Sierkstra et al., 1991), indicating that linear homologous ends are not obligatory for targeted integration. Occasionally, we also observed targeted integration of circular plasmids containing large integration boxes, but integration was always less efficient as compared to linear plasmids (K. N. Faber \& P. Haima, unpublished results). This resembles the situation in $S$. cerevisiae, where the integration frequency of circular replicating plasmids is always less than $1 \%$ (Orr-Weaver et al., 1983).

Southern hybridization analyses revealed chromosomal structures which were consistent with classical single and double cross-over recombinations. Both single-copy and multi-copy tandem integrations (two and three copies) were observed. The chromosomal structure of one of the pHIP112 transformants was consistent with a $2 \times$ cross-over integration followed by $1 \times$ cross-over integration of an additional (recircularized) plasmid copy. Recently, these combinations of $1 \times$ and $2 \times$ crossover integrations have also been reported for $P$. pastoris (Romanos et al., 1990).

Despite the linearization within the integration boxes, only a minority of our plasmid constructs integrated at the homologous site in the genome (integration frequencies amounted to 1,3 and $22 \%$ for pHIP 11 , pHIP112 and pHIP111, respectively). This appears very akin to the situation in $S$. cerevisiae, in which integration frequencies of linearized replicating plasmids can vary from 6 to
$50 \%$ (Orr-Weaver et al., 1983). The observed differences in integration frequencies of plasmids pHIP $11, \mathrm{pHIP} 112$ and pHIP111 might be due to differences in the length of the integration boxes. We observed that by increasing the length of the pHIP11 integration box from 800 to $1260 \mathrm{bp}$, the integration frequencies were approximately doubled (P. Haima \& G. J. Swaving, unpublished results). Alternatively, integrations might occur with variable frequencies at different loci, as has been observed with S. cerevisiae (Orr-Weaver et al., 1981) and Sch. pombe (Grimm \& Kohli, 1988). In the cases in which no targeted integration was found, we observed intact autonomous plasmids. Apparently, the DSB in these plasmids had been repaired without recombination with the homologous site on the genome. This view was strenghtened by the observation that DSB in nonhomologous plasmid regions were repaired as efficiently as in homologous plasmid regions. In both cases, linearization increased the transforming activity of the plasmids up to 15-fold as compared to circular plasmids. Homologyindependent DSB repair has been observed before in $H$. polymorpha (Gleeson et al., 1986), S. cerevisiae (OrrWeaver et al., 1981, 1983; Orr-Weaver \& Szostak, 1983; Kunes et al., 1985; Perera et al., 1988) and Sch. pombe (Grimm \& Kohli, 1988). A striking difference from our observations is that these authors never observed a stimulating effect of plasmid linearization on transformation frequencies; in $S$. cerevisiae in fact the opposite was often observed, namely that linearization had a strong negative effect on plasmid transformation frequencies (Orr-Weaver et al., 1981). A possible explanation for this discrepancy may be that linear plasmid molecules are more efficiently internalized in our transformation system. This could represent a characteristic feature of either the host $H$. polymorpha or the transformation procedure.

Non-recombinational DSB repair was precise in $68 \%$ of the cases of linearization within the coding region of the $L E U 2$ gene of plasmid pHIP 1 and $50 \%$ in the case of $B g l$ II- and NcoI-linearized pHIP11. In those cases in which DSB repair was not precise, plasmids contained small rearrangements encompassing the lost restriction site. Comparable data were reported for $S$. cerevisae: up to $50 \%$ of the transformants resulting from nonrecombinational DSB repair contained deleted plasmids (Orr-Weaver \& Szostak, 1983; Kunes et al., 1985).

The plasmid integration strategy for $H$. polymorpha presented in this study involves the use of replicating plasmids containing recombinogenic DSB within $H$. polymorpha genomic sequences. Since integration of these plasmids can be achieved by either single or double cross-over recombinations, it can be used as a strategy to routinely stabilize genes for gene expression purposes and to modify or inactivate genes of interest. Recently we 
successfully applied this integration strategy to modify the amine oxidase gene (K. N. Faber and others, unpublished). However, plasmid integration efficiency is relatively low $(1-22 \%)$, due to efficient repair of DSB in $H$. polymorpha and the presence of an active $H$. polymorpha replication origin within the $S$. cerevisiaederived $L E U 2$ fragment. A possible way to enhance the efficiency is to use a stabilizing procedure, which involves growing the transformants for 50-100 generations in non-selective medium and subsequently selecting for segregants still showing the transformant phenotype (Roggenkamp et al., 1986). By use of such stabilizing procedures, Sierkstra et al. (1991) succeeded in obtaining $50 \%$ targeted integration of a circular replicating plasmid in $H$. polymorpha. The main disadvantage of this method is that in all the other cases $(50 \%)$ the plasmid integrated at nonhomologous loci. Using the above stabilizing procedure for integration of pHIP111, we observed up to $80 \%$ nonhomologous integrations (K. N. Faber, unpublished). Therefore, the use of nonreplicating plasmids is probably the most attractive way to obtain high frequencies of homologous recombination. The construction of such suicide plasmids is likely to be very valuable in order to further increase the efficiencies of targeted integration in $H$. polymorpha.

We thank Martin Bokranz and Jim Cregg for helpful discussions and Anton Nolle for photography. Peter Haima was supported by Unilever Research Laboratories, Vlaardingen. Klaas Nico Faber was supported by the Netherlands Technology Foundation (STW), which is subsidized by the Netherlands Organization for the Advancement of Pure Research (NWO).

\section{References}

Berardi, E. \& Thomas, D. Y. (1990). An effective transformation method for Hansenula polymorpha. Current Genetics 18, 169-170.

Beburov, M. Y., ZlocheWsKy, M. L., Michailover, V. M., Semenova, V. D., Gracheva, V. D. \& LahtcheV, K. (1990). Transformation of methylotrophic yeast Hansenula polymorpha with linear DNA fragments. In The Fifteenth International Conference on Yeast Genetics and Molecular Biology, The Hague, The Netherlands (book of abstracts), p. 118. Edited by S. G. Oliver. Chichester: John Wiley.

Broach, J. R., Strathern, J. N. \& Hicks, J. B. (1979). Transformation in yeast: development of a hybrid cloning vector and isolation of the CAN1 gene. Gene 8, 121-133.

Bruinenberg, P. G., Evers, M., Waterham, H. R., Kuipers, J., ARnBerg, A. C. \& AB, G. (1989). Cloning and sequencing of the peroxisomal amine oxidase gene from Hansenula polymorpha. Biochimica et Biophysica Acta 1008, 157-167.

CregG, J. M., Barringer, K. J., Hessler, A. Y. \& Madden, K. R. (1985). Pichia pastoris as a host system for transformations. Molecular and Cellular Biology 5, 3376-3385.

CregG, J. M., Van der Klei, I. J., Sulter, G. J., Veenhuis, M. \& Harder, W. (1990). Peroxisome deficient mutants of Hansenula polymorpha. Yeast 6, 87-97.

CREGG, J. M. \& MAdDEN, K. R. (1987). Development of yeast transformation systems and construction of methanol utilization defective mutants of Pichia pastoris by gene disruption. In Biological
Research on Industrial Yeasts, vol. II, pp. 1-18. Edited by G. G. Stewart, I. Russel, R. D. Klein \& R. R. Hiebsch. Boca Raton, FL: CRC Press.

Dohmen, R. J., Strasser, W. M., Honer, C. B. \& Hollenberg, C. P. (1991). An efficient transformation procedure enabling long-term storage of competent cells of various yeast genera. Yeast 7, 691-692.

Dower, W. J., Miller, J. F. \& Ragsdale, C. W. (1988). High efficiency transformation of $E$. coli by high voltage electroporation. Nucleic Acids Research 16, 6127-6145.

ECKART, M. (1988). Klonierung und Charakterisierung der Gene für Dihydroxyacetonesynthase und Methanoloxidase aus der Methylotrophen Hefen Hansenula polymorpha. PhD thesis, University of Düsseldorf, FRG.

Fellinger, A. J., Verbakel, J. M. A., Veale, R. A., Sudbery, P. E., BOM, I. J., OVERBEEKE, N. \& VerRIPS, C. T. (1991). Expression of the $\alpha$-galactosidase from Cyamopsis tetragonoloba (Guar) by Hansenula polymorpha. Yeast 7, 463-473.

FINCHAM, J. R. S. (1989). Transformation in fungi. Microbiological Reviews 53, 148-170.

GleEson, M. A. \& Sudbery, P. E. (1988). Genetic analysis in the methylotrophic yeast Hansenula polymorpha. Yeast 4, 293-303.

GleEson, M. A., OrToRi, G. S. \& SUdBery, P. E. (1986). Transformation of the methylotrophic yeast Hansenula polymorpha. Journal of General Microbiology 132, 3459-3465.

GrimM, C. \& KoHLI, J. (1988). Observations on integrative transformation in Schizosaccharomyces pombe. Molecular and General Genetics 215, 87-93.

HANAHAN, D. (1983). Studies on transformation of Escherichia coli with plasmids. Journal of Molecular Biology 166, 557-580.

HinNen, A., Hicks, J. B. \& Fink, G. R. (1978). Transformation of yeast. Proceedings of the National Academy of Sciences of the United States of America 75, 1929-1933.

Hodgkins, M. A., Sudbery, P. E., Kerry-Williams, S. \& Goodey, A. (1990). Secretion of human serum albumin from Hansenula polymorpha. In The Fifteenth International Conference on Yeast Genetics and Molecular Biology, The Hague, The Netherlands (book of abstracts), p. 435. Edited by S. G. Oliver. Chichester: John Wiley.

HofFMAN, C. S. \& Winston, F. (1987). A ten-minute DNA preparation from yeast efficiently releases autonomous plasmids for transformation of Escherichia coli. Gene 57, 267-272.

Holmes, D. S. \& Quigley, M. (1981). A rapid boiling method for the preparation of bacterial plasmids. Analytical Biochemistry 114, 193.

Horinouchi, H. \& WeIsBlum, B. (1982a). Nucleotide sequence and functional map of pE194, a plasmid that specifies inducible resistance to macrolide, lincosamide and streptogramin type $B$ antibiotics. Journal of Bacteriology 150, 804-814.

HorinouChI, H. \& Weisblum, B. (1982b). Nucleotide sequence and functional map of $\mathrm{pC194}$, a plasmid that specifies inducible chloramphenicol resistance. Journal of Bacteriology 150, 815-825.

IsH-HoRowicz, D. \& BURKE, F. J. (1979). Rapid and efficient cosmid cloning. Nucleic Acids Research 9, 2989-2999.

Janowicz, A. Z., Melber, K., MerCKelbach, A., Jacobs, E., Harford, N., Comberbach, M. \& Hollenberg, C. P. (1991). Simultaneous expression of the $S$ and $L$ surface antigens of hepatitis $B$, and formation of mixed particles in the methylotrophic yeast, Hansenula polymorpha. Yeast 7, 431-443.

Klebe, R. J., Harriss, J. V., Sharp, Z. D. \& Douglas, M. G. (1983). A general method for polyethylene-glycol-induced genetic transformation of bacteria and yeast. Gene 25, 331-341.

KunES, S., BotsteIN, D. \& FoX, M. S. (1985). Transformation of yeast with linearized plasmid DNA, formation of inverted dimers and recombinant plasmid products. Journal of Molecular Biology 184, 375-387.

Ledeboer, A. M., Edens, L., Maat, J., Visser, C., Bos, J. W., VERRIPS, C. T., JANOWICZ, Z., ECKART, M., ROGGENKAMP, R. \& HolleNBERG, C. P. (1985). Molecular cloning and characterization of a gene coding for methanol oxidase in Hansenula polymorpha. Nucleic Acids Research 13, 3063-3082.

Mead, D. A., Szczesna-Skorupa, E. \& Kemper, B. (1986). Singlestranded DNA 'blue' T7 promoter plasmids: a versatile tandem promoter system for cloning and protein engineering. Protein Engineering 1, 67-74. 
Meissner, P. S., Sisk, W. P. \& Berman, M. L. (1987). Bacteriophage cloning system for the construction of directional cDNA libraries. Proceedings of the National Academy of Sciences of the United States of America 84, 4171-4175.

OrR-Weaver, T. L. \& SzostaK, J. W. (1983). Yeast recombination: the association between double strand gap repair and crossing-over. Proceedings of the National Academy of Sciences of the United States of America 80, 4417-4421.

OrR-Weaver, T. L., Szostak, J. W. \& Rothstein, R. J. (1981). Yeast transformation: a model system for the study of recombination. Proceedings of the National Academy of Sciences of the United States of America 78, 6354-6358.

OrR-Weaver, T. L., Szostak, J. W. \& Rothstein, R. J. (1983). Genetic applications of yeast transformation with linear and gapped plasmids. Methods in Enzymology 101, 228-245.

Perera, J. R., Glasunov, A. V., Glaser, V. M. \& Boreiko, A. V. (1988). Repair of double-strand breaks in plasmid DNA in the yeast Saccharomyces cerevisiae. Molecular and General Genetics 213, $421-424$

Roggenkamp, R., Hansen, H., Eckart, M., Janowicz, Z. \& HOLLENBERG, C. P. (1986). Transformation of the methylotrophic yeast Hansenula polymorpha by autonomous replication and integration vectors. Molecular and General Genetics 202, 302-308.

Romanos, M. A., Rayment, F., Beesley, K. M. \& ClaRe, J. J. (1990). Expression of the Bordetella pertussis (whooping cough) P.69 antigen in Saccharomyces cerevisiae and Pichia. In The Fifteenth International Conference on Yeast Genetics and Molecular Biology, The Hague, The Netherlands (book of abstracts), p. 428. Edited by S. G. Oliver. Chichester: John Wiley.

SAKAGUCHI, J. \& YAMAMoto, M. (1982). Cloned ural locus of Schizosaccharomyces pombe propagates autonomously in this yeast assuming a polymeric form. Proceedings of the National Academy of Sciences of the United States of America 79, 7819-7823.

Sambrook, J., Fritsch, E. F. \& Maniatis, T. (1989). Molecular Cloning, a Laboratory Manual. Cold Spring Harbor, NY: Cold Spring Harbor Laboratory.

Shen, S. H., Bastien, L., Nguyen, T., Fung, M. \& Slilaty, S. N. (1989). Synthesis and secretion of hepatitis B middle surface antigen by the methylotrophic yeast Hansenula polymorpha. Gene 84, 303-309.

Sherman, F., FinK, G. R. \& Hicks, J. B. (1986). Methods in Yeast
Genetics, a Laboratory Manual. Cold Spring Harbor, NY: Cold Spring Harbor Laboratory.

Sierkstra, L. N., Verbakel, J. M. A. \& Verrips, C. T. (1991). Optimisation of a host/vector system for heterologous gene expression by Hansenula polymorpha. Current Genetics 19, 81-87.

SOUTHERN, E. M. (1975). Detection of specific sequences among DNA fragments separated by gel electrophoresis. Journal of Molecular Biology 98, 503.

Sudbery, P. E., Gleeson, M. A., Veale, R. A., Ledeboer, A. M. \& ZoETMULDER, M. C. M. (1988). Hansenula polymorpha as a novel yeast system for expression of heterologous genes. Biochemical Society Transactions 16, 1081-1083.

Tikmomirova, L. P., IKonomova, R. N. \& Kuznetsova, E. N. (1986) Evidence for autonomous replication and stabilization of recombinant plasmids in the transformants of yeast Hansenula polymorpha. Current Genetics 10, 741-747.

Tikhomirova, L. P., Ikonomova, R. N., Kuznetsova, E. N., Fodor, I. I., BYSTR YKh, L. V., AMINOVA, L. R. \& TROTSENKo, Y. A. (1988). Transformation of methylotrophic yeast Hansenula polymorpha: cloning and expression of genes. Journal of Basic Microbiology 28, 343-351.

VAN DeR Klei, I. J., Harder, W. \& Veenhuis, M. (1991 a) Biosynthesis and assembly of alcohol oxidase, a peroxisomal matrix protein in methylotrophic yeasts: a review. Yeast 7, 195-209.

VAN DeR Klei, I. J., Harder, W. \& Veenhuis, M. (1991 $b$ ). Methanol metabolism in a peroxisome-deficient mutant of Hansenula polymorpha: a physiological study. Archives of Microbiology 156, 15-23.

Veale, R. A., Giusseppin, M. L. F., Van Eijk, H. M. J., Sudbery, P. E. \& VERRIPS, C. T. (1992). Development of a strain of Hansenula polymorpha for the efficient expression of guar $\alpha$-galactosidase. Yeast 8, 361-372.

Veenhuis, M., Van DiJken, J. P. \& HaRder, W. (1983). The significance of peroxisomes in the metabolism of one-carbon compounds in yeast. Advances in Microbiological Physiology 24, 1-82.

VEenhUIS, M. \& HARDER, W. (1991). Microbodies. In The Yeasts, vol. 4, 2nd edn, pp. 601-653. Edited by A. H. Rose \& J. S. Harrison. London: Academic Press.

Yanisch-PerRon, C., Vieira, J. \& Messing, J. (1985). Improved M13 phage cloning vectors and host strains: nucleotide sequences of M13mp18 and pUC19 vectors. Gene 33, 103-119. 